\title{
Red mason bee (Osmia bicornis) thermal preferences for nest sites and their effects on offspring survival
}

\author{
Monika Ostap-Chec (D), Justyna KIERAt, Karolina KuszewsKa, Michal WoycIechowsKi
}

Institute of Environmental Sciences, Jagiellonian University, Gronostajowa 7, 30-387, Krakow, Poland

Received 30 June 2020 - Revised 2 February 2021 - Accepted 6 April 2021

\begin{abstract}
Ectotherms usually require a narrow range of thermal conditions for development; thus, parental selection of oviposition sites is crucial. In a field experiment, we investigated female solitary red mason bee (Osmia bicornis ) preferences for potential nest site temperatures and their effects on offspring development. The results showed that bees detected and avoided nest sites with high temperatures $\left(28^{\circ} \mathrm{C}\right)$ and often chose cooler $\left(24^{\circ} \mathrm{C}\right)$ or ambient temperatures (average $18-20^{\circ} \mathrm{C}$ ). This is a protective behaviour because offspring survival decreases with increasing nest temperature, mostly due to mortality at the egg stage. Elevated temperatures also led to weight loss in adult bees. However, hot nest temperatures appeared to deter adults or kill parasite larvae, as the highest numbers of parasites were observed in unheated nests. We concluded that choosing the proper temperature for nests is an important element in bee life strategies, especially in warming environments.
\end{abstract}

\section{Osmia bicornis / nest site preferences / temperature / development / body mass}

\section{INTRODUCTION}

Many species of animals provide direct care to their offspring during development to increase their survival rate (Clutton-Brock 1991). Choosing the right nest site by parents is one of the most important factors impacting offspring survival (Trumbo 1996; Refsnider and Janzen 2010). Parental selection of an oviposition site is crucial, especially for ectotherms whose body temperature depends on the ambient temperature (AT) and who develop successfully under a narrow range of microhabitat conditions. These types of animals, which often live in environments with fluctuating temperatures (daily and seasonal), should be equipped with behavioural or/and physiological mechanisms necessary to recognize and avoid

Corresponding author: M. Ostap-Chec, ostap.monika@gmail.com

Manuscript editor James Nieh adverse nesting conditions. Indeed, many ectotherms choose locations with favourable thermal microhabitats (Trumbo 1996; Pike et al. 2012; Potter et al. 2009). Flat-rock spiders choose oviposition sites beneath large and hot rocks, which provide the most suitable conditions for developing offspring and are convenient for adults (Pike et al. 2012). Similarly, to ensure the best conditions for colony development, ponerine ants select nesting sites under large, hot rocks (Thomas 2002). Ants are able to regulate the temperature at which their brood is raised by relocating them among numerous nest chambers and selecting the temperature most suitable for offspring development (Roces and Núñez 1989).

Temperature is an extremely important environmental factor that affects many life history traits of animals, particularly those that depend on external sources of body heat (Stillwell and Fox 2005). Temperature conditions during development have an impact on the sizes of the body 
and its cells (Partridge et al. 1994; Atkinson 1994; Czarnoleski et al. 2013; Kierat et al. 2017) as well as development time (Atkinson 1994; Radmacher and Strohm 2011). Significant departure from optimal development temperatures may cause decreased fitness and high mortality in offspring (Groh et al. 2004; Bosch and Kemp 2004; Sgolastra et al. 2011; Giejdasz and Fliszkiewicz 2016). Notably, increased temperatures can also indirectly impact ectotherms. While warming could benefit high-latitude insects by increasing the opportunities for oviposition and foraging, it may simultaneously be nullified by indirect costs of increased parasite activity (Thomas and Blanford 2003; Forrest and Chisholm 2017).

Climatic changes observed in recent decades have prompted an expansion of knowledge on the possible effects. Overall, mean temperatures are rising, extreme weather conditions, such as heat waves, are more frequent and intense, the spring season is starting earlier than normal, and the growing seasons are prolonged (Menzel et al. 2006; Schwartz et al. 2006; IPCC 2014). These factors have many consequences for ectotherms (Deutsch et al. 2008), such as the disruption of synchronization between insects and their host plants (Memmott et al. 2007; Schenk et al. 2018) or the shifting of animal ranges towards the poles (Chen et al. 2011). Extreme weather events, such as heat waves, may cause significant decreases in fitness parameters (Fischer et al. 2014), while prolonged summers and delayed winters may disrupt the start of obligatory diapause, resulting in high mortality (Sgolastra et al. 2011). Global climate change also affects pollinating insects, whose drastic decline is already being observed (Biesmeijer et al. 2006; Koh et al. 2016; Powney et al. 2019; Soroye et al. 2020).

Solitary bees play a crucial role in pollination (Kremen 2008). The red mason bee (Osmia bicornis L. ) is a well-known pollinator that is commonly used not only in crop pollination but also in research investigations (Wilkaniec and Radajewska 1997; Bosch and Kemp 2002; Krunić and Stanisavljević 2006). Characteristics of its life cycle (such as nesting in pre-existing cavities, overwintering in the adult stage inside the cocoon, and producing one generation per year) are representative of many species of its genus, particularly the subgenus Osmia, members of which are very similar in their life cycles (Sgolastra et al. 2019). It is also easy to experimentally handle, and methods of rearing are well established (Gruber et al. 2011; Sedivy and Dorn 2014). This makes red mason bees good candidates for model species, e.g. in studies of pesticide toxicity, the effect of environmental pollution, ecological stoichiometry, or interspecific interactions (Fliszkiewicz et al. 2012a; Szentgyörgyi et al. 2017; Kierat et al. 2018; Sgolastra et al. 2019; Filipiak 2019; Eeraerts et al. 2020). Females fly throughout the spring until early summer. They nest in preexisting cavities, such as empty stalks of plants (reed stems), under the bark of trees, or in the cracks of wood. Each nest consists of linearly aligned brood cells provisioned with pollen mixed with some regurgitated nectar (Raw 1972). On the top of each food provision, a female lays a single egg and separates each cell with a loam partition (Raw 1972). The hatched larvae consume food, spin a cocoon, and pupate to complete their development by the end of summer. They overwinter inside the cocoon as adults and emerge the following spring (Raw 1972; Giejdasz and Wilkaniec 2002). Although red mason bee females often aggregate, similar to many other solitary bee species, they do not engage in cooperative rearing, and each of them independently provides food for its own offspring. Red mason bees have many natural enemies, such as cleptoparasites that creep into their nests and eat pollen provisions, predators, and parasitoids killing bee larvae (Krunić et al. 2005; Fliszkiewicz et al. 2012a; Giejdasz and Fliszkiewicz 2016). The importance of particular species in restricting red mason bee populations depends on the locality, but among the most important nest parasites frequently listed are the mites Chaetodactylus osmiae and fly Cacoxenus indagator (Zajdel et al. 2014). Both species feed on nest contents: pollen and nectar collected by red mason females, in most cases causing developing bee death from starvation. Other, slightly less frequently encountered Osmia parasites are parasitoids: wasp Monodontomerus obscurus and predatory beetle Trichodes apiarius (Krunić et al. 2005).

While some studies have explored the impact of different temperatures during development on 
offspring survival, body mass, organ size, and body size in O. bicornis (Bosch and Kemp 2003, 2004; Radmacher and Strohm 2010; Sgolastra et al. 2011; Giejdasz and Fliszkiewicz 2016; Kierat et al. 2017), little is known about female preferences for thermal conditions in nests and whether they affect oviposition site choice. It is still unknown what consequences for offspring carry behind its choices. Increased temperature may confer protection against gut pathogens (Palmer-Young et al. 2019); however, there is a gap in knowledge about the connection between thermal conditions inside the nest and the rate of ectoparasites. It is important to elucidate that knowledge because of ongoing climate change.

In this study, we explored whether females preferred nest sites with specific temperatures and analysed the effects of nest temperature choice on offspring survival. Accordingly, the rate of settlement in nests with particular temperatures was assessed, and mortality at different developmental stages and adult body mass of offspring were analysed. Particular attention was also paid to the degree of mortality caused by parasites and to parasite species diversity.

\section{METHODS}

\subsection{Nest preparation and observation}

The experiment was conducted in the area of the experimental apiary of the Institute of Environmental Sciences, Jagiellonian University (Krakow, Southern Poland, temperate climate) in 2017. The apiary is located in the immediate vicinity of the Institute and is surrounded by meadows and bushes.

Initially, 12 artificial nest boxes were prepared, each consisting of a bundle of 100 reed stems (each is a single nest). In four of the nest boxes, the temperature was not manipulated (AT nest boxes). The other eight boxes were each interlaced with a cable heater with a thermoregulator that is often used in terrariums (Figure S1, Supplementary materials). These thermoregulators control the temperature so that when it drops below the set level, the heaters turn on and heat to the set minimum temperature. The minimum temperature (MT) was set at $24^{\circ} \mathrm{C}$ in four of those nest boxes (MT $24^{\circ} \mathrm{C}$ ) and $28^{\circ} \mathrm{C}$ in the remaining boxes (MT $28^{\circ} \mathrm{C}$ ). Importantly, only the minimum temperature was regulated, while the maximum temperature inside the nest box was dependent on the conditions outside, resulting in fluctuations. Each nest box was wrapped with aluminium foil and placed in a styrofoam case (Figure S2, Supplementary materials). At the beginning of April, four sets of nest boxes were prepared, each consisting of three different nest boxes (AT, MT $24^{\circ} \mathrm{C}$, and MT $28^{\circ} \mathrm{C}$ ), and placed in different locations on the experimental apiary tool house walls (A: southeast wall, $\sim 0.5 \mathrm{~m}$ above the ground; B: southeast wall, $\sim 1.5 \mathrm{~m}$ above the ground; $\mathrm{C}$ : northwest wall, $\sim 0.5 \mathrm{~m}$ above the ground; D: northwest wall, $\sim 1.5 \mathrm{~m}$ above the ground; Figure S3, Supplementary materials). To each of the nest boxes, a cardboard container with 40 cocoons was attached (sex ratio 1:1, a small incision was made in each cocoon, and the colour of the hairs on the bee's clypeus was used as an indication of sex; females, black hair; males, whiteish-yellow hair). The cocoons originated from the stock at the Institute of Environmental Science, Jagiellonian University, Krakow.

During the whole experimental period, the temperature inside each nest box was recorded every $2 \mathrm{~h}$ by a data logger (Thermochron iButton DS1921G, Maxim/Dallas iButton Products, accuracy $\pm 1{ }^{\circ} \mathrm{C}$, measurements to the nearest $0.5^{\circ} \mathrm{C}$ ) placed between reed stems. To observe the settlement rate in the reed stems, a photo of each nest box was taken every 2 days from 29 May to 27 June 2017. Nest boxes were heated until $10 \mathrm{Au}-$ gust. Considering that $O$. bicornis development normally takes approximately 14 weeks from oviposition to adult eclosion, we assumed that by that date, all offspring were in the imago stage (Raw 1972; Giejdasz and Wilkaniec 2002). In the autumn, nests were moved to an unheated utility room to mimic natural conditions of obligatory winter diapause.

\subsection{Mortality, body mass, and parasite pressure}

In the spring of the following year (midMarch), the mortality, parasitization rates, and body mass of the red mason bee offspring were 
analysed. First, 35 reed stems were randomly removed from each nest box. After opening the stems, the number of cells with uneaten pollen (mortality at the egg stage), dead larvae, cocoons, and parasitized cells was counted. The species of parasites were noted. The obtained cocoons were placed in plastic boxes at room temperature, and twice a day, the hatched bees were released into the wild. After 8 days, the number of unhatched bees was counted, allowing a comparison of adult mortality in each treatment group. Furthermore, 10 female and 10 male bees (in cocoons) were selected from each nest box to compare the body mass of individuals ( $\sim 40$ individuals for each temperature treatment). Bees were sexed as mentioned above.

\subsection{Data analysis}

The data from data loggers were evaluated to determine whether the temperatures in the nest boxes were maintained at the assumed levels. Based on these data, the average temperatures with standard deviations (SDs) of the nest boxes were calculated.

The number of occupied reed stems in each nest box, assessed based on the digital photos, was analysed using the Cox proportional hazard regression model (package survival in R). Two fixed factors were included in the model: the temperature in the nest boxes (AT vs. MT $24^{\circ} \mathrm{C}$ vs. MT $28^{\circ} \mathrm{C}$ ) and their location (A vs. B vs. C vs. D), as well as their interaction.

To compare the mortality of offspring, a series of Poisson regression models with offsets was used $(n=11)$. Models included the temperature (AT vs. MT $24^{\circ} \mathrm{C}$ vs. MT $28^{\circ} \mathrm{C}$ ) and location (A vs. B vs. C vs. D) as fixed factors, as well as the log-transformed number of bees that survived to a given stage as an offset. The interaction between temperature and location was nonsignificant in all models and was hence removed in each case. Detailed factor comparisons were made with the significance level adjusted after the Bonferroni correction (for temperature factor: $p<0.017$; for location factor: $p<0.025)$. In the first model, the analysis of mortality caused by parasites was performed. In that case, the number of cells with parasites to the total number of built cells was used as the dependent variable. In the second model, the analysis of mortality at the egg stage was performed, with the number of cells with uneaten pollen to the total number of built cells (without parasitized cells) as the dependent variable. Next, in the third model, the analysis of mortality at the larval stage was performed, and the number of dead larvae to the total number of individuals who survived the egg stage was used as the dependent variable. In the fourth model, to analyse the mortality of bees inside cocoons, the number of bees that hatched to the total number of bees that survived to cocoon spinning was used as the dependent variable. Finally, to analyse the overall survival of bees, another model included the number of bees that died at all stages of development to the total number of cells built as the dependent variable.

Body mass was analysed using a general linear model with three fixed factors (AT vs. MT $24^{\circ} \mathrm{C}$ vs. MT $28^{\circ} \mathrm{C}$ ), location (A vs. B vs. C vs. D), sex (male vs. female), and the interaction between sex and temperature. Other interactions were nonsignificant and were removed from the model. All statistical analyses were performed using the statistical programming language $\mathrm{R}$ ( $\mathrm{R}$ Core Team 2020).

\section{RESULTS}

\subsection{Temperature treatment}

The average temperature in each nest box and standard deviation (Table S1, Supplementary materials) showed that the lowest temperatures and the greatest fluctuations occurred in AT nest boxes without heaters, as expected $\left(18.7 \pm 6.8^{\circ} \mathrm{C}\right.$; mean $\pm \mathrm{SD})$. In the nest boxes kept at a MT of $24^{\circ} \mathrm{C}$, the mean temperature was relatively high $\left(26.0 \pm 2.5^{\circ} \mathrm{C}\right.$; mean $\left.\pm \mathrm{SD}\right)$ but not as high as that in the hottest nest boxes $\left(29.9 \pm 3.5^{\circ} \mathrm{C}\right.$; mean \pm $\mathrm{SD})$. The obtained temperature values allowed the comparison of results between treatments (Figure S4, supplementary materials). During the experiment, one of the heaters broke (location B, MT $24^{\circ} \mathrm{C}$, Figure S4, Supplementary materials), and the temperature inside this nest box reached a much higher maximum value than in the other nests. This particular nest box was excluded from 
all analyses. The whole set of nest boxes (B location) was also excluded from nesting preference analysis.

\subsection{Nesting preferences}

There were differences in the rate of nest settlement between temperatures (Figure 1). Specifically, compared to AT nest boxes without heaters, there was no difference in the rate of settlement in MT $24^{\circ} \mathrm{C}$ boxes $(z=-0.388, p=$ 0.692), but there was a significant drop in MT $28^{\circ} \mathrm{C}$ boxes $(z=-5.664, p<0.001)$. Nest boxes heated to MT $24^{\circ} \mathrm{C}$ were settled significantly more often than those heated to MT $28^{\circ} \mathrm{C}(z=$ $-5.585, p<0,001)$. Location $\left(x^{2}=232.31, p<\right.$ $0.001)$, as well as the interaction of temperature and location $\left(x^{2}=49.895, p<0.001\right)$, were significant. The highest rate of settlement was observed in location D (northwest side, higher), and this location differed significantly from nests located on the same wall but lower (D vs. C location; $z=-8,940, p<0.001$, Figure S5, supplementary materials). Nest boxes located down on the walls but on opposite sides of the tool house also differ significantly (A vs. C: $z=$
$8.230, p<001)$. The interaction between temperature and location revealed that in the hottest nest boxes, the higher location increased their attractiveness $(z=4.418, p<0.001)$.

\subsection{Mortality and survival}

The analysis of overall survival of offspring (Figure 2) demonstrated that, compared to nest boxes with AT, only high temperature inside nests (MT $\left.28^{\circ} \mathrm{C}\right)$ caused reduced survival of bees $(z=$ $-5.864, p<0.001$ ), while boxes with MT $24^{\circ} \mathrm{C}$ did not differ significantly $(z=-1.183, p=$ 0.237 ). In nest boxes with MT $24^{\circ} \mathrm{C}$, the overall survival rate was significantly higher than that in boxes with $\mathrm{MT} 28^{\circ} \mathrm{C}(z=-4.539, p<0.001)$. Location had no effect on the overall survival of bees (Table I, Model 1).

The impact of parasites on bee survival depended on temperature in the nest (Table I, Model 2) and was stronger in AT nest boxes than in heated nest boxes with MT $24^{\circ} \mathrm{C}(z=-2.577$, $p<0.010)$ and $\mathrm{MT} 28^{\circ} \mathrm{C}(z=-3.062, p<0.003)$. In nest boxes with $24^{\circ} \mathrm{C}$ and MT $28^{\circ} \mathrm{C}$, mortality caused by parasites was on similar level $(z=$ $0.318, p=0.750$; Figure 3). In AT nest boxes,

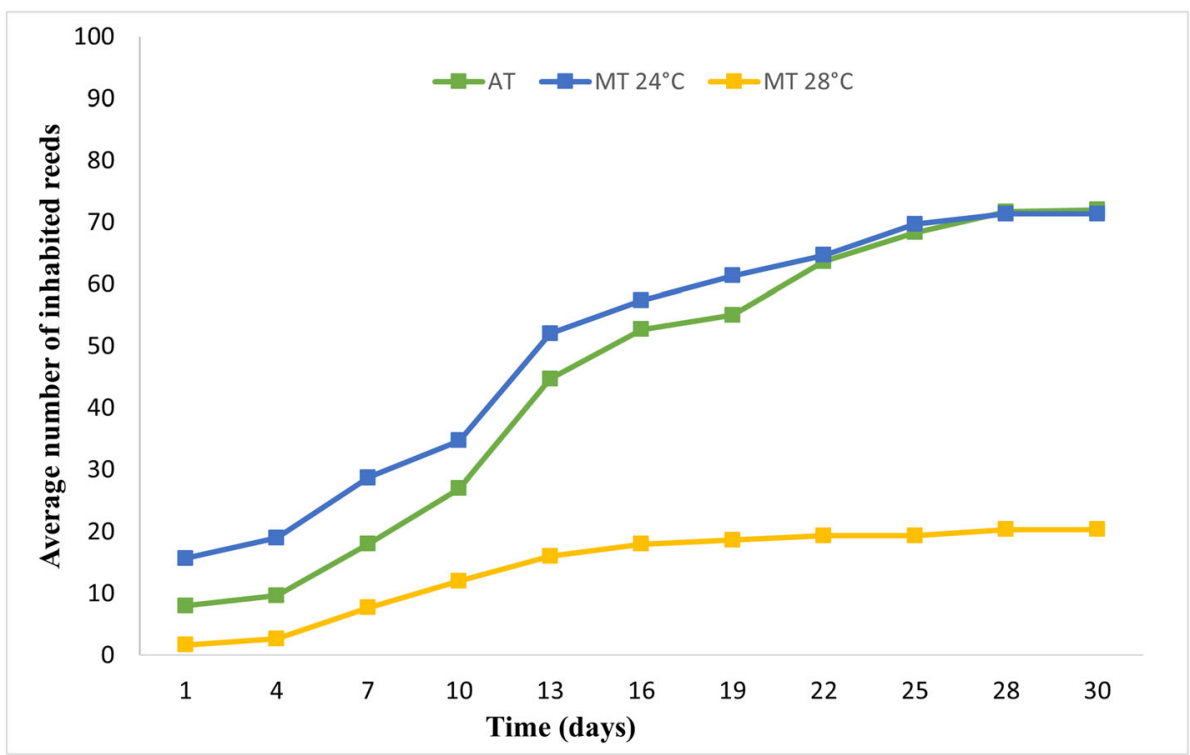

Figure 1. Average number of reed stems inhabited by bees as a function of time depending on temperature treatment. 


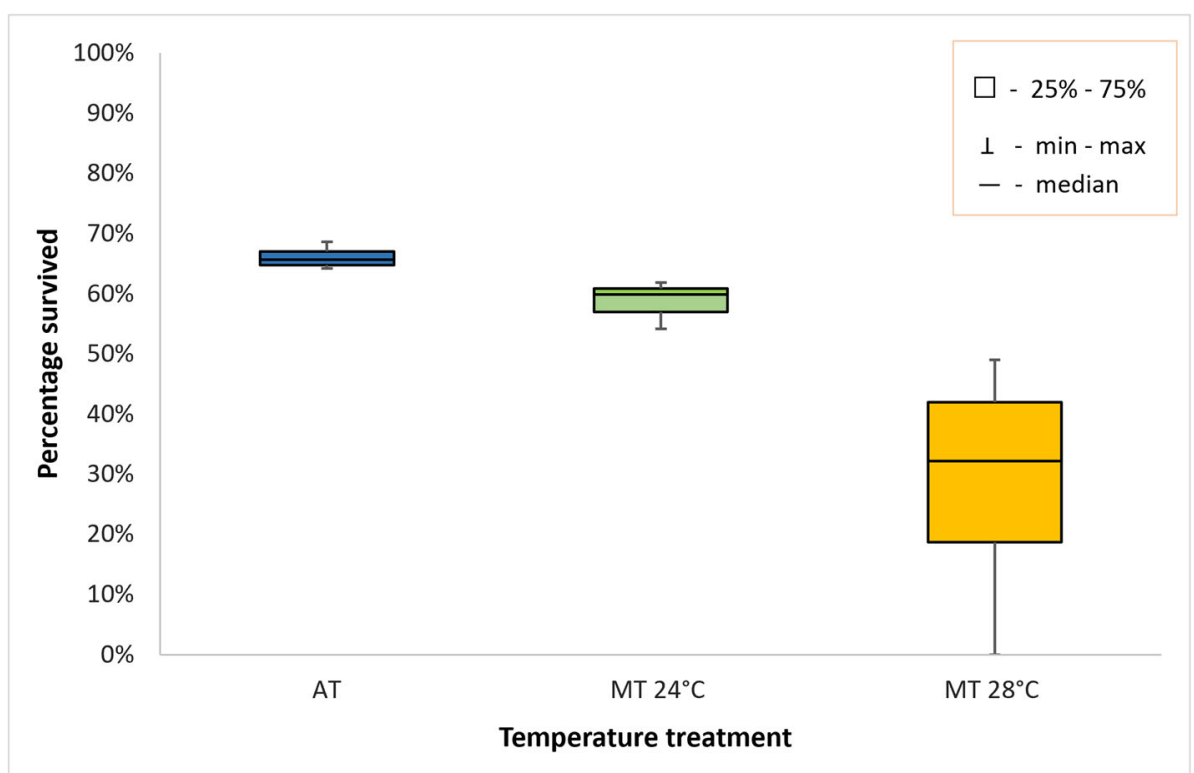

Figure 2. Percent of bees that survived to adulthood and hatched from cocoons in the different temperature treatments.

five parasite species were observed (Chaetodactylus osmiae, Trogoderma glabrum, Cacoxenus indagator, Monodontomerus obscurus, and Trichodes apiarius), with most cells (23) inhabiting Ch. osmiae mites. In nest boxes with MT $24^{\circ} \mathrm{C}$ and MT $28^{\circ} \mathrm{C}$, only two parasite species were found (T. glabrum and C. indagator). Nest box location significantly

Table I. Accurate results for Poisson regression models used for analysis of overall survival rate and mortality caused at each stage of development and caused by parasites

\begin{tabular}{lllllll}
\hline \multicolumn{1}{c}{ Analysis } & \multicolumn{1}{c}{ Factor } & Df & Deviance & Resid. df & Resid. dev. & Pr (>chi) \\
\hline Model 1 & Null & & & 10 & 51.823 & \\
Overall survival rate & Temperature & 2 & 37.950 & 5 & 8.235 & $5.745 \mathrm{e}-09$ \\
& Location & 3 & 5.638 & 7 & 46.185 & 0.1306 \\
Model 2 & Null & & & 10 & 79.292 & \\
Mortality caused by parasites & Temperature & 2 & 32.862 & 8 & 46.430 & $7.312 \mathrm{e}-08$ \\
& Location & 3 & 40.307 & 5 & 6.123 & $9.173 \mathrm{e}-09$ \\
Model 3 & Null & & & 10 & 79.003 & \\
Mortality at the egg stage & Temperature & 2 & 65.858 & 8 & 13.145 & $5.002 \mathrm{e}-15$ \\
& Location & 3 & 11.646 & 5 & 1.499 & 0.008698 \\
Model 4 & Null & & & 10 & 35.134 & \\
Mortality at the larvae stage & Temperature & 2 & 16.0032 & 8 & 19.131 & 0.0003349 \\
& Location & 3 & 0.9316 & 5 & 18.199 & 0.8177853 \\
Model 5 & Null & & & 9 & 17.3659 & \\
Mortality inside the cocoon & Temperature & 2 & 7.6618 & 7 & 9.7041 & 0.02169 \\
& Location & 3 & 2.8929 & 4 & 6.8111 & 0.40843 \\
\hline
\end{tabular}




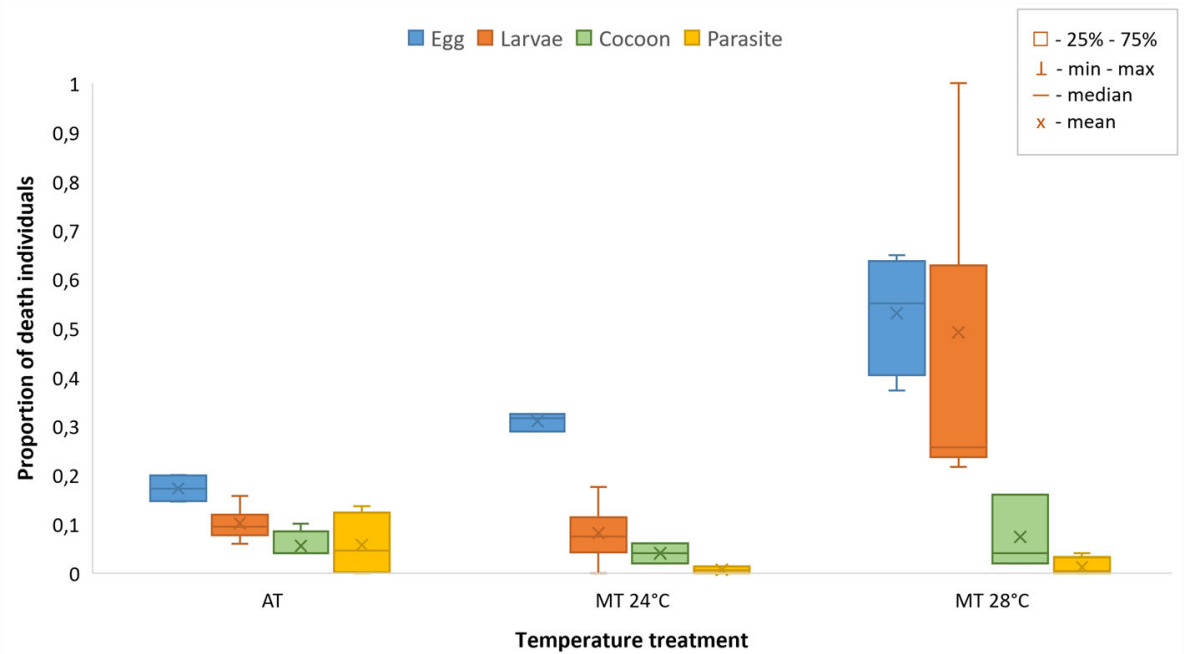

Figure 3. Average proportion of dead individuals at different stages of development and caused by parasites.

impacts parasite pressure (Table I, Model 2). Most cells settled by parasites ( 52 cells) were found on the southeast wall, independent of location A (lower) and B (higher) $(z=1.966, p=0.049$, not significant after Bonferroni correction). On the other (northwest) wall, only 5 cells were inhabited by parasites.

Mortality analysis at the egg stage showed a significant impact of temperature. Compared to AT nest boxes, egg mortality was significantly higher in both nest boxes with MT $24^{\circ} \mathrm{C}(z=$ $3.795, p<0.001)$ and $\mathrm{MT} 28^{\circ} \mathrm{C}(z=7.814, p<$ $0.001)$. Boxes with heaters also differed significantly from each other $(z=4.476, p<0.001$; Figure 3). Location had no impact on egg mortality (Table I, Model 3).

Similar to eggs, larvae died more often in boxes with MT $28^{\circ} \mathrm{C}$ than in AT boxes $(z=3.922, p<$ 0.001 ), but larvae in boxes with MT $24^{\circ} \mathrm{C}$ did not differ from AT nest boxes $(z=0.050, p=0.960$; Figure 3). Location also did not impact larval mortality (Table I, Model 4).

At the cocoon stage, mortality in AT nest boxes did not differ from that in MT $24^{\circ} \mathrm{C}(z=0.567, p$ $=0.571)$ and $\mathrm{MT} 28^{\circ} \mathrm{C}(z=2.147, p=0.032$, not significant after Bonferroni correction). There were also no differences between bee mortality in boxes with MT $24^{\circ} \mathrm{C}$ and MT $28^{\circ} \mathrm{C}(z=2.171$, $p=0.030$, not significant after Bonferroni correction; Figure 3), and location had no significant impact (Table I, Model 5).

\subsection{Body mass}

There were differences in body mass between temperatures $(F=27.736, p<0.001)$, locations $(F=2.908, p=0.036)$, and sexes $(F=234.787$, $p<0.001)$. The interaction between temperature and sex also showed significant differences $(F=$ $4.8621, p<0.009$, Figure 4). In both sexes, the body mass of individuals decreased with increasing temperature, but only in the case of females were these differences statistically significant (Figure 4).

\section{DISCUSSION}

Ectotherms, which usually require a specific range of thermal conditions, usually choose nest sites that will maximize progeny development (Roces and Núñez 1989; Trumbo 1996; Thomas 2002; Pike et al. 2012). As with studies on other species (Thomas 2002; Pike et al. 2012), our results revealed that nesting sites selected by O. bicornis females are not random. Bees prefer nests higher above ground level than near to it. Although the location had an effect on the rate of settlement in nest boxes, in all three locations, the same pattern was observed. In two of the hottest free nest boxes, almost none of the reed stems were inhabited by red mason bees. In one case, bees inhabited some of the available reed stems but still less than cooler nest boxes. Therefore, in 


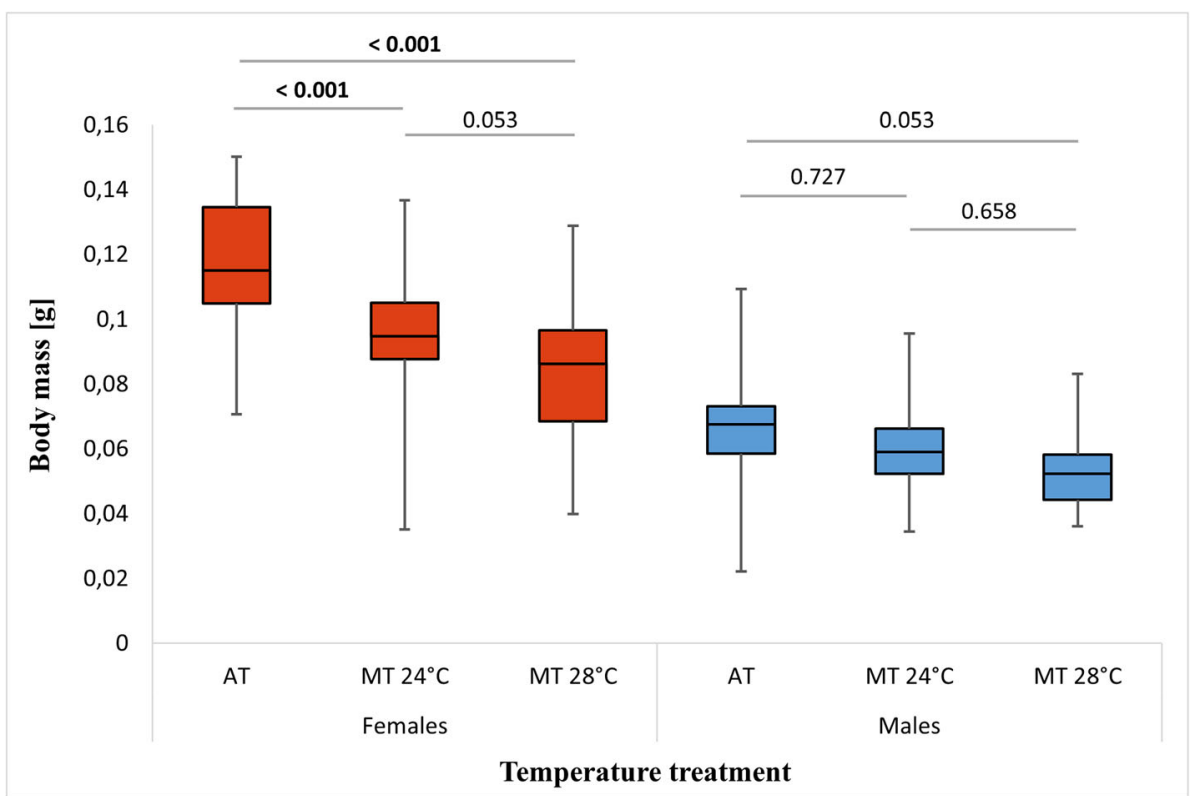

Figure 4. Body mass of males and females with their cocoons under different temperature treatments. Values at the top of the graph indicate $p$-values for each comparison. Lines inside squares indicate means, squares indicate quartiles, and whiskers indicate standard errors.

each location, bees were much more likely to inhabit the nests maintained at AT or the nests with an MT of $24^{\circ} \mathrm{C}$ than the nests with a MT of $28^{\circ} \mathrm{C}$. These results indicate that bees recognize temperatures in their potential nests and choose those that are better for progeny development. This behaviour may be crucial in adapting to ongoing climate change. However, overheating during development is not the only danger of climate change. Bees will also have to survive prolonged summers and warm winters, which also affect red mason bee fitness (Bosch and Kemp 2004; Sgolastra et al. 2011).

The right female's choice appears to affect survival outcome for offspring. Our results of survival to adulthood showed that the best conditions for development occurred in the nest boxes in which the temperature was not manipulated. In the nest boxes with a MT of $24^{\circ} \mathrm{C}$, slightly fewer bees completed development and reached adulthood, but the most dramatic effects were observed in bees that developed in the nest boxes with MT of $28^{\circ} \mathrm{C}$. It shows that a slight, even a few degree Celsius increase in temperature does not have a large effect on the survival rate of offspring, while high temperatures above $28^{\circ} \mathrm{C}$ are dangerous. Our results show that even in the wild, a relatively high proportion (1/3) of bees do not complete development and survive into adulthood. Considering that the results were very similar $(31.4-35.8 \%)$ in all four nests without heaters, they possibly represent the natural rate of mortality in $O$. bicornis species. Elevating the temperature up to $28^{\circ} \mathrm{C}$ caused a significant and dangerous increase in mortality. As detailed analyses have shown, increased thermal conditions inside the nest affect egg mortality the most. As the temperature rises to $28^{\circ} \mathrm{C}$, egg mortality increases rapidly, reaching $53 \%$. Such high temperature is also not conducive to the development of larvae and significantly increases their mortality. Considering this result in the context of ongoing climate change, the most dangerous condition for solitary bee development will be the hot spring season. Nevertheless, it seems unlikely that on our study side, the temperatures in April or May will reach the temperatures used in the experiment. Later stages of development 
(inside the cocoon) seemed to be the least sensitive to elevated temperatures. Generally, parasitism had less effect on bee mortality, but it varied depending on the temperature inside the nest boxes. The greatest parasitism level was observed in nests maintained in AT, while in nest boxes with heaters, it declined significantly. Very different distributions of mortality in each stage of development were observed in the nests maintained at AT. In this case, a lower mortality rate occurred during the egg stage but was higher during development inside the cocoon and due to parasitism. Studies on another species in the Osmia genus showed that natural mortality at the egg stage was 6$31 \%$ in O. lignaria and $15 \%$ in O. cornuta (Bosch et al. 2000; Bosch and Vicens 2005). Similar to our results, Giejdasz and Fliszkiewicz (2016) also observed the highest mortality during the initial stages of development, but only at $25^{\circ} \mathrm{C}$ and $\mathrm{AT}$. Bees raised at $30^{\circ} \mathrm{C}$ and $20^{\circ} \mathrm{C}$ showed low mortality at the egg stage. In turn, opposite results were obtained by Radmacher and Strohm (2011), who studied the effect of constant and fluctuating temperatures in nests on the survival of red mason bees. They showed that the temperature inside the nest did not affect any stages of development from egg to pupa but strongly affected the survival of adult individuals $(100 \%, 86.2 \%)$, especially those who developed under relatively high-temperature conditions (constant $27.5^{\circ} \mathrm{C}$; fluctuations $25-35^{\circ} \mathrm{C}$, respectively). The conflicting results of these studies may be due to methodological differences in the later stages of the experiments. Giejdasz and Fliszkiewicz (2016) cooled the nests to $15^{\circ} \mathrm{C}$ in mid-summer and then overwintered them at $4^{\circ} \mathrm{C}$, starting at the end of October, whereas Radmacher and Strohm (2011) maintained bees in particular temperature treatments until 2 October and then transferred them to $4{ }^{\circ} \mathrm{C}$ conditions for overwintering. It is also possible that the studied populations of $O$. bicornis originating from other populations differed in resistance to temperature changes.

The mortality rate caused by parasites differs significantly between temperature treatments. All encountered species were known red mason bee parasite species (Krunić et al. 2005). However, most of the parasites were observed only inside unheated nests. In these nest boxes, the most abundant parasites were Ch. osmiae mites, which were not observed in other nest boxes. We suspect that elevated temperatures in nests affect the development of mites. Studies on another species from the Chaetodactylus genus showed that their development proceeded without disturbance until $37.5^{\circ} \mathrm{C}$, above which the mortality of mites reached $100 \%$ (Ahn et al. 2016). Another parasite that was widely observed in unheated nest boxes but only sporadically in boxes with controlled temperatures was $C$. indagator. These results indicate that the larvae of this parasite species probably have a limited tolerance to increased temperature, especially considering that Giejdasz and Fliszkiewicz (2016) obtained similar results. The results of mortality caused by parasites allow us to predict that with increasing temperatures or, more often, heat waves, parasite pressure will decrease (Thomas and Blandford 2003).

The temperature inside the nest box also influenced the body mass of adult bees. We showed that both sexes of $O$. bicornis experienced the same pattern of weight loss due to elevated temperatures in nests; however, it was more clearly seen in the case of females. In females that developed inside the hottest nests, body weight was reduced by approximately one-third. This phenomenon can be explained by the fact that at high temperatures, bees develop faster and reach adulthood sooner than they would at low temperatures (Radmacher and Strohm 2011; Giejdasz and Fliszkiewicz 2016). This means that those bees experience a prolonged prewinter period, which is unfavourable. During the prewinter period, bees do not have access to food, but outdoor temperatures do not allow winter diapause. Therefore, a prolonged summer period is associated with great energetic costs in the form of fat body depletion and lipid loss, resulting in weight loss (Bosch et al. 2010; Radmacher and Strohm 2010; Sgolastra et al. 2011; Fliszkiewicz et al. 2012b). There are also presumptions that body weight loss 
is mediated by the accessibility of food at the initial stages of development. In a study by Radmacher and Strohm (2010), bees raised at $30^{\circ} \mathrm{C}$ left much of their food provision uneaten. Perhaps in hot conditions, pollen becomes dry and dehydrated and hence less absorbable by the larva. However, some researchers claim that despite body mass loss, bees hatching from cocoons in favourable conditions are able to compensate for energy shortages (Sgolastra et al. 2016). Another possible explanation is that weight loss occurs due to a reduction in cell and organ sizes according to the temperature-size rule (Atkinson 1994). This hypothesis was confirmed by Kierat et al. (2017), who demonstrated that red mason bees that developed at higher temperatures had smaller cells. Therefore, we suspect that body weight loss might also be related to thermal plasticity in ectotherms, enabling adjustment of the optimal cell membrane area according to the respiration rate at a given temperature (Kozłowski et al. 2003; Czarnoleski et al. 2013; Kierat et al. 2017). At higher temperatures, an organism's demand for oxygen increases; hence, tissues composed of small cells provide an extensive network of cell membranes for oxygen distribution (Subczynski et al. 1989; Czarnoleski et al. 2013; Kierat et al. 2017). Body mass loss is particularly adverse given that it has a direct impact on female reproductive success. Smaller (also lightweight) females (Kierat et al. 2017) have difficulties providing enough provision for their offspring, which results in shifting the sex ratio of offspring towards males and lower body mass of daughters (Seidelmann et al. 2010).

Our results demonstrate that increased nest temperatures caused multiple negative effects in red mason progeny, including increased mortality and reduced body mass. The results suggest that bees recognize the thermal conditions inside nests and avoid high-risk oviposition sites. This behaviour is crucial considering ongoing climate change. It can be expected that as temperatures progressively increase, females will select cooler nest sites for oviposition. On the other hand with increasing temperatures, the pressure of parasites decreases. Therefore, we can conclude that hotter nesting sites have negative effects on the development of offspring, but at the same time decrease the pressure of parasites.

\section{ACKNOWLEDGEMENTS}

The authors wish to thank Pawel Mielczarek for helping with the construction of the nest boxes and American Journal Experts for language editing (funded by the Ph.D. Students' Association of Jagiellonian University).

\section{AUTHOR CONTRIBUTIONS}

MOC, JK, and MW conceived this research and designed the experiments. MOC and JK performed the experiments. MOC and $\mathrm{KK}$ analysed the data. MOC, KK, MW, and JK wrote the paper and participated in the revisions. All authors read and approved the final manuscript.

\section{FUNDING}

This study was funded by Jagiellonian University (grant DS/BiNoZ/INoŚ/761/17-20).

\section{DATA AVAILABILITY}

The datasets generated during and/or analysed during the current study are available from the corresponding author on reasonable request.

\section{DECLARATIONS}

Ethical approval No approval of research ethics committees was required to accomplish the goals of this study because the experimental work was conducted with an unregulated invertebrate species.

Conflict of interest The authors declare no competing interests.

Préférences thermiques de l'abeille maçonne rouge (Osmia bicornis) pour les sites de nidification et leurs effets sur la survie de la progéniture.

Osmia bicornis / préférences pour les sites de nidification / température / développement / masse corporelle. 
Thermische Präferenzen der Roten Mauerbiene (Osmia bicornis) für Neststandorte und ihre Auswirkungen auf das Überleben ihrer Nachkommen.

Osmia bicornis / Neststandortpräferenzen / Temperatur / Entwicklung / Körpermasse.

\section{REFERENCES}

Ahn JJ, Son Y, He Y, Lee E, Park YL (2016) Effects of temperature on development and voltinism of Chaetodactylus krombeini (Acari: Chaetodactylidae): Implications for climate change impacts. PLoS ONE 11:e0161319. https://doi.org/10.1371/journal. pone.0161319

Atkinson D (1994) Temperature and organism size a biological law for ectotherms? Adv Ecol Res 25:1-58.

Biesmeijer JC, Roberts SPM, Reemer M et al (2006) Parallel declines in pollinators and insect-pollinated plants in Britain and the Netherlands. Science 313:351-354. https://doi.org/10.1126/science.1127863

Bosch J, Kemp WP (2002) Developing and establishing bee, species as crop pollinators: the example of Osmia spp. (Hymenoptera: Megachilidae) and fruit trees. Bull Entomol Res 92:3-16. doi:https://doi.org/10.1079 /BER2001139

Bosch J, Kemp WP (2003) Effect of wintering duration and temperature on survival and emergence time in males of the orchard pollinator Osmia lignaria (Hymenoptera: Megachilidae). Environ Entomol 32:711-716. https://doi.org/10.1603/0046-225x-32.4.711

Bosch J, Kemp WP (2004) Effect of pre-wintering and wintering temperature regimes on weight loss, survival, and emergence time in the mason bee Osmia cornuta (Hymenoptera: Megachilidae). Apidologie 35:469-479. https://doi.org/10.1051/apido:2004035

Bosch J, Vicens N (2005) Sex allocation in the solitary bee Osmia cornuta: do females bahave in agreement with Fishers's theory? Behav Ecol Sociobiol 59:124-132. https://doi.org/10.1007/s00265-005-0017-8

Bosch J, Kemp WP, Peterson SS (2000) Management of Osmia lignaria (Hymenoptera: Megachilidae) populations for almond pollination: methods to advance bee emergence. Environ Entomol 29:874-883. https://doi. org/10.1603/0046-225x-29.5.874

Bosch J, Sgolastra F, Kemp WP (2010) Timing of eclosion affects diapause development, fat body consumption and longevity in Osmia lignaria, a univoltine, adultwintering solitary bee. J Insect Physiol 56:1949-1957. https://doi.org/10.1016/j.jinsphys.2010.08.017

Chen IC, Hill JK, Ohlemüller R, Roy DB, Thomas CD (2011) Rapid range shifts of species associated with high levels of climate warming. Science 333:1024 1026. https://doi.org/10.1126/science.1206432

Clutton-Brock TH (1991) The evolution of parental care. Princeton University Press, Princeton

Czarnoleski M, Cooper BS, Kierat J, Angilletta MJ (2013) Flies developed small bodies and small cells in warm and in thermally fluctuating environments. J Exp Biol 216:2896-2901. https://doi.org/10.1242/jeb.083535

Deutsch CA, Tewksbury JJ, Huey RB et al (2008) Impacts of climate warming on terrestrial ectotherms across latitude. Proc Natl Acad Sci U S A 105:6668-6672. https://doi.org/10.1073/pnas.0709472105

Eeraerts M, Pisman M, Vanderhaegen R, Meeus I, Smagghe G (2020) Recommendations for standardized oral toxicity test protocol for larvae of solitary bees, Osmia spp. Apidologie 51:48-60. doi:https://doi.org/10.1007/s13592-019-00704-w

Filipiak M (2019) Key pollen host plants provide balanced diets for wild bee larvae: A lesson for planting flower strips and hedgerows. J Appl Ecol 56(6):1410-1418. https://doi.org/10.1111/1365-2664.13383

Fischer K, Klockmann M, Reim E (2014) Strong negative effects of simulated heat waves in a tropical butterfly. $\mathrm{J}$ Exp Biol 217:2892-2898. https://doi.org/10.1242 /jeb. 106245

Fliszkiewicz M, Kuśnierczak A, Szymaś B (2012a) The accompanying fauna of solitary bee Osmia bicornis (L.) Syn. Osmia rufa (L.) nests settled in different biotopes. J Apic Sci 56(1):51-58. https://doi. org/10.2478/v10289-012-0006-X

Fliszkiewicz M, Giejdasz K, Wasielewski O, Krishnan N (2012b) Influence of winter temperature and simulated climate change on body mass and fat body depletnion during diapause in adults of solitary bee, Osmia rufa (Hymenoptera:Megachlidae). Environ Entomol 41(6):1621-1630. https://doi.org/10.1603/EN12004

Forrest JRK, Chisholm SPM (2017) Direct benefits and indirect costs of warm temperatures for highelevation populations of a solitary bee. Ecology 98:359-369. https://doi.org/10.1002/ecy.1655

Giejdasz K, Fliszkiewicz M (2016) Effect of temperature treatment during development of Osmia rufa L., on mortality, emergence and longevity of adults. J Apic Sci 60:221-232. https://doi.org/10.1515/JAS-2016-0029

Giejdasz K, Wilkaniec Z (2002) Individual development of the red mason bee (Osmia rufa L., Megachilidae) under natural and laboratory conditions. J Apic Sci 46:51-57.

Groh C, Tautz J, Rössler W (2004) Synaptic organization in the adult honey bee brain is influenced by broodtemperature control during pupal development. Proc Natl Acad Sci U S A 101(12):4268-4273. https://doi. org/10.1073/pnas.0400773101

Gruber B, Eckel K, Everaars J, Dormann CF (2011) On managing the red mason bee (Osmia bicornis) in apple orchards. Apidologie 42:564-576. doi:https://doi. org/10.1007/s13592-011-0059-z

IPCC (2014) Climate Change 2014: Impacts, adaptation, and vulnerability. In: Field CB, Barros VR, Dokken 
DJ, Mach KJ, Mastrandrea MD, Bilir TE, Chatterjee M, Ebi KL, Estrada YO, Genova RC, Girma B, Kissel ES, Levy AN, MacCracken S, Mastrandrea PR, White LL (eds) Part A: Global and Sectoral Aspects. Contribution of Working Group II to the Fifth Assessment Report of the Intergovernmental Panel on Climate Change. Cambridge University Press, Cambridge, United Kingdom and New York, NY, USA, pp 1132

Kierat J, Szentgyörgy H, Czarnoleski M, Woyciechowski M (2017) The thermal environment of the nest affects body and cell size in the solitary red mason bee (Osmia bicornis L.). J Term Biol 68:39-44. https://doi. org/10.1016/j.jtherbio.2016.11.008

Kierat J, Miler K, Celary M, Woychiechowski M (2018) Interspecific interactions in solitary Aculeata - is the presence of heterospecifics important for females establishing nests? Bull Entomol Res 108:35-39. doi:https://doi.org/10.1017/S0007485317000475

Koh I, Lonsdorf EV, Williams NM, Brittain C, Issacs R, Gibbs J, Ricketts TH (2016) Modelling the status, trends, and impacts of wild bee abundance in the United States. Proc Natl Acad Sci U S A 113(1):140145. https://doi.org/10.1073/pnas.1517685113

Kozłowski J, Konarzewski M, Gawelczyk AT (2003) Cell size as a link between noncoding DNA and metabolic rate scaling. Proc Natl Acad Sci U S A 100:1408014085. https://doi.org/10.1073/pnas.2334605100

Kremen C (2008) Crop pollination services from wid bees. In: Bee pollination in agricultural ecosystem. pp 10-26

Krunić M, Stanisavljević L (2006) Augmentation of managed populations of Osmia cornuta and O. rufa (Hymenoptera: Megachilidae) in Southeastern Europe. Eur Journal Entomol 103:695-697. https://doi. org/10.14411/eje.2006.091

Krunić M, Stanisavljević L, Pinzauti M, Felicioli A (2005) The accompanying fauna of Osmia cornuta and Osmia rufa and effective measures of protection. Bull Insect 58:141-152.

Memmott J, Craze PG, Waser NM, Price MV (2007) Global warming and the disruption of plant-pollinator interactions. Ecol Lett 10:710-717. https://doi. org/10.1111/j.1461-0248.2007.01061.x

Menzel A, Sparks TH, Estrella N et al (2006) European phenological response to climate change matches the warming pattern. Glob Change Biol 12:1969-1976. https://doi.org/10.1111/j.1365-2486.2006.01193.x

Palmer-Young EC, Ngor L, Nevarez RB, Rothman JA, Raffel TR, McFredrick QS (2019) Temperature dependence of parasitic infection and gut bacterial communities in bumble bees. Environ Microbiol 21:47064723. https://doi.org/10.1111/1462-2920.14805

Partridge L, Barrie B, Fowler K, French V (1994) Evolution and development of body size and cell size in Drosophila melanogaster in response to temperature. Evolution 48:1269-1276. https://doi.org/10.1111 j.1558-5646.1994.tb05311.x

Pike DA, Webb JK, Shine R (2012) Hot mothers, cool eggs: nest-site selection by egg-guarding spiders accommodates conflicting thermal optima. Funct Ecol
26:469-475. https://doi.org/10.1111/j.13652435.2011.01946.x

Potter K, Davidowitz G, Woods HA (2009) Insect eggs protected from high temperatures by limited homeothermy of plant leaves. J Exp Biol 212:3448-3454. https://doi.org/10.1242/jeb.033365

Powney GD, Carvell C, Edwards M, Morris RKA, Roy HE, Woodcock BA, Isaac NJB (2019) Widespread losses of pollinatig insects in Britain. Nat Commun 10:1018. https://doi.org/10.1038/s41467-019-08974-9

Radmacher S, Strohm E (2010) Factors affecting offspring body size in the solitary bee (Hymenoptera, Megachilidae). Apidologie 41:169-177. https://doi. org/10.1051/apido/2009064

Radmacher S, Strohm E (2011) Effects of constant and fluctuating temperatures on the development of the solitary bee Osmia bicornis (Hymenoptera: Megachilidae). Apidologie 42:711-720. https://doi. org/10.1007/s13592-011-0078-9

Raw A (1972) The biology of the solitary bee Osmia rufa (L.) (Megachilidae). T Roy Ent Soc London 124:213229. https://doi.org/10.1111/j.1365-2311.1972. tb00364.x

Refsnider JM, Janzen FJ (2010) Putting eggs in one basket: ecological and evolutionary hypotheses for variation in oviposition-site choice. Annu Rev Ecol Evol Syst 41:39-57. https://doi.org/10.1146/annurev-ecolsys102209-144712

Roces F, Núñez JA (1989) Brood translocation and circadian variation of temperature preference in the ant Camponotus mus. Oecologia, 81:33-37. https://doi. org/10.1007/BF00377006

Schenk M, Krauss J, Holzschuh A (2018) Desynchronizations in bee-plant interactions cause severe fitness losses in solitary bees. J Anim Ecol 87:139-149. https://doi.org/10.1111/13652656.12694

Schwartz MD, Ahas R, Aasa A (2006) Onset of spring starting earlier across the Northern Hemisphere. Glob Change Biol 12:343-351. https://doi.org/10.1111 j.1365-2486.2005.01097.x

Sedivy C, Dorn S (2014) Towards a sustainable management of bees of the subgenus Osmia (Megachilidae; Osmia) as fruit tree pollinators. Apidologie 45: 88105. https://doi.org/10.1007/s13592-013-0231-8

Seidelmann K, Ulbrich K, Mielenz N (2010) Conditional sex allocation in Red Mason bee, Osmia rufa. Behav Ecol Sociobiol 64:337-347. https://doi.org/10.1007 /s00265-009-0850-2

Sgolastra F, Kemp WP, Buckner JS, Pitts-Singer TL, Maini S, Bosch J (2011) The long summer: Pre-wintering temperatures affect metabolic expenditure and winter survival in a solitary bee. J Insect Physiol 57:16511659. https://doi.org/10.1016/j.jinsphys.2011.08.017

Sgolastra F, Arnan X, Pitts-Singer TL, Maini S, Kemp WP, Bosch J (2016) Pre-wintering conditions and postwinter performance in a solitary bee: Does diapause impose an energetic cost on reproductive success? Ecol 
Entomol, 41:201-210. https://doi.org/10.1111 /een.12292

Sgolastra F, Hinarejos S, Pitts-Singer TL, Boyle NK, Joseph T, Lūckmann J, Raine NE, Singh R, Williams NM, Bosch J (2019) Pesticide exposure assessment paradigm for solitary bees. Environ Entomol 48(1):22-35. https://doi.org/10.1093/ee/nvy105

Soroye R, Newbold T, Kerr J (2020) Climate change contributes to widespread declines among bumble bees across continents. Science 367(6478):685-688. https://doi.org/10.1126/science.aax8591

Stillwell RC, Fox CW (2005) Complex patterns of phenotypic plasticity: interactive effects of temperature during rearing and oviposition. Ecology 86:924-934. https://doi.org/10.1890/04-0547

Subczynski WK, Hyde JS, Kusumi A (1989) Oxygen permeability of phosphatidylcholine-cholesterol membranes. Proc Natl Acad Sci U S A 86:4474-4478. https://doi.org/10.1073/pnas.86.12.4474

Szentgyörgyi H, Moroń D, Nawrocka A, Tofilski A, Woyciechowski M (2017) Forewing structure of the solitary bee Osmia bicornis developing on heavy metal pollution gradient. Ecotoxicology 26:10311040. https://doi.org/10.1007/s10646-017-1831-2
Thomas ML (2002) Nest site selection and longevity in the ponerine ant Rhytidoponera metallica (Hymenoptera, Formicidae). Insect Soc 49:147-152. https://doi. org/10.1007/s00040-002-8294-y

Thomas MB, Blanford S (2003) Thermal biology in insectparasite interactions. Trends Ecol Evol 18:344-350. https://doi.org/10.1016/S0169-5347(03)00069-7

Trumbo ST (1996) Parental care in invertebrates. Advances in the Study of Behaviour, 25:3-51. https://doi. org/10.1016/S0065-3454(08)60329-0

Wilkaniec Z, Radajewska B (1997) Solitary bee Osmia rufa L. (Apoidea, Megachilidae) as pollinator of strawberry cultivated in an unheated plastic tunnel. Acta Hort 439:489-493. https://doi.org/10.17660 /actahortic.1997.439.83

Zajdel B, Kucharska K, Kucharski D, Fliszkiewicz M, Gąbka J (2014) Accompanying fauna of red mason bees in annual and perennial nesting sites. Med Weter 70(12):745-749.

Publisher's note Springer Nature remains neutral with regard to jurisdictional claims in published maps and institutional affiliations. 